\title{
As leis do monte
}

\author{
Carlos Freire
}

Ambiciosa, complexa, absolutamente excéntrica. Son algúns dos adxectivos que acoden ao pensamento a medida que avanzamos na lectura de Casa Skylab, unha obra coa que Santiago Jaureguizar (Bilbo, 1965) acadou este ano o premio Xerais de novela. $O$ pouso que deixa no lector a visita a estas páxinas ten variados matices dos que a continuación daremos conta, pero se unha sensación prevalece sobre as demais ao rematar o periplo é a de ficar na metade de ningunha parte. Neste senso, a cita de V. S. Naipaul que serve de pórtico á obra, onde se nos di que unha novela debe empezar polo medio para rematar tamén no medio, constitúe unha anotación á marxe da escritura que resulta moi útil para orientarse.

O inicio de narración constitúe toda unha declaración de principios: o parvo Antón Duracell, vestido cun disfrace de coello, tenta trazar un círculo no ar usando un coitelo da matanza. A escena ofrece unha clave importante para coñecer a estructura da obra, que tenderá á circularidade. En Casa Skylab todo flúe, principio e fin poden atoparse en calquera punto dese círculo que constitúe $\mathrm{Ne}$ gueira de Rodríguez, unha vila onde a natureza se mostra violenta, salvaxe, ou, por dicilo na terminoloxía do autor, bravú. Jaureguizar móvese en múltiples direccións, situándose sempre in media res do relato e convertendo a Antón Duracell no vector que conduce aos lectores até cada personaxe e suceso. O valor que se arroga o parvo da vila é tan grande que Jaureguizar até lle confire o poder de falar cos mortos do camposanto, é dicir, o poder de situarse fóra do círculo de personaxes. El é o único que se mostra absolutamente libre, a diferencia do resto dos veciños, que parecen auténticos monicreques. Poida incluso que Antón Duracell non sexa tan parvo como parece, aínda que nisto Jaureguizar é insistente; chámalle arrudo, babeco, babiolo, badoco, boubexo, boubo, imbécil, mamalón, paifoco, panoio, papahostias, palabea, pampiroleiro e se cadra algunha cousa máis. Pese a todo, Antón Duracell non é o membro máis freak de Negueira. Os irmáns siameses que rexentan o pub «Sempre en Galicia», Almudena, que suplanta a súa nai morta na cama do pai, ou os fantasmais membros da comuna hippie que viven na Outra Beira teñen máis papeletas para ocupar esa posición de privilexio.

Para o tratamento do tema, os modelos dos que se serve Jaureguizar podemos atopalos na televisión, en Internet, no cine e na parte máis popular dos me- 
dios de comunicación. De forma constante e intencionada, a novela fai publicidade de todo tipo de marcas comerciais (o ceo pode ter «a cor dunha Pepsi»; os ollos de alguén son «grandes e rechamantes como dúas chapas de Carlsberg»), ofrece un exceso de información (crea ruído), aprópiase do léxico sen lustrar da Administración e os poderes fácticos, e tamén recorre con frecuencia a frases periodísticas que aínda non se solidificaron na linguaxe cotiá (Antón atópase ledo pola súa «homologación social»). Jaureguizar móstrase aquí deliberadamente antipoético e contrarretórico, conformando, pese a todo, unha poética propia que é a que dota a novela de personalidade. Exemplos disto hainos por todas as partes, pero con frecuencia fan niño nas descricións de lugares (Uns amieiros «comparten un regato en réxime de propiedade horizontal»), nas imaxes, e sobre de todo nos momentos en que unha soa palabra ou unha frase curta ocupan toda unha liña, como se fosen un verso ou un primeiro plano cinematográfico, remarcando unha forza expresiva da que estas palabras carecen por si soas.

Coa intención de manterse sempre no medio da narración, Jaureguizar introduce cambios constantes na figura no narrador, que pasa da terceira á segunda persoa, que unhas veces é omnisciente e outras non, que detén o discurso para que fale algún personaxe, e que incluso reclama a atención de quen le ou daqueles que están oíndo a historia, non se sabe moi ben, en singular e tamén en plural. Coido que este é o punto máis feble da obra. Trátase dun recurso inoperante e bastante arbitrario. Pola súa parte, a investigación que leva a cabo o policía Alberte Sanxil resulta excesivamente caricaturesca, incluso nunha novela tan turbulenta como Casa Skylab. É unha mágoa, ademais, que o autor non aproveitara todas as posibilidades que lle ofrecía o personaxe de Daniel Rodríguez «Patapao», que permanece sempre nun discreto segundo plano.

Casa Skylab é unha filla do seu tempo. Aínda que os feitos se desenvolven no corazón das montañas de Galiza, é unha obra moderna e incluso posmoderna. Por un lado, bótalle un pulso á realidade cotiá; polo outro, todo nas súas páxinas remite á parodia, ao simulacro, rematando borracha de si mesma. 